\title{
Factors Influencing Job Satisfaction and Its Impact on Job Loyalty
}

\author{
Athar Waqas \\ Department of Management Sciences, The Islamia University of Bahawalpur, Pakistan
}

\section{Umair Bashir}

Department of Management Sciences, The Islamia University of Bahawalpur, Pakistan

Muhammad Fahad Sattar

Department of Management Sciences, The Islamia University of Bahawalpur, Pakistan

Hafiz Muhammad Abdullah

Department of Management Sciences, The Islamia University of Bahawalpur, Pakistan

Imtiaz Hussain

Department of Management Sciences, The Islamia University of Bahawalpur, Pakistan

Waqas Anjum

Department of Management Sciences, The Islamia University of Bahawalpur, Pakistan

MuhammadAftab Ali

Department of Management Sciences, The Islamia University of Bahawalpur, Pakistan

\section{RizwanArshad}

Lecturer, Department of Management Sciences,

The Islamia University of Bahawalpur (Pakistan)

rizwan.arshad@iub.edu.pk

DOI:10.5296/ ijld.v4i2.6095 URL: http://dx.doi.org/10.5296/ ijld.v4i2.6095 


\begin{abstract}
Many studies have showed the job satisfaction level and the loyalty to their organizations yet these researches have not been conducted in the developing countries. The purpose of the study is to find the job satisfaction level, its impact on loyalty and the factors affecting it, to help efficient and effective management system in the developing countries like Pakistan. A model was developed which includes the factors affecting job satisfaction, their relations and effects on job loyalty. Questionnaire was developed to collect the data for job satisfaction level in various organizations. Convenient sampling was used and 148 questionnaires were filled from the employees of different private and public organizations. Statistically, Reward and recognition and workplace environment were most influencing factors to Job satisfaction, but participation in decision making and job satisfaction has insignificant relationship. Moreover, there is also positive relation between job satisfaction and job loyalty. Human resource management (HRM) claims to measure job satisfaction in developed or multi-national companies. Definitely, in under developed countries like Pakistan, these applications are rarely used. So, this paper supports use of HRM applications in the developing countries. It will help managers to better understand satisfaction level of employees and can motivate them.
\end{abstract}

Keywords: Pakistan, Job satisfaction, Job Loyalty, Reward and Recognition, Empowerment, Participation in Decision making, Work place environment.

\title{
1. Introduction
}

For almost all organizations, employees are the vital resource and they represent an important investment, if they are satisfied and loyal to their jobs. Based on the organization's policy, management develops their bonus packages, appraisal and work system and training programs. Basically, these are designed to gain their loyalty for the organization and which leads to highest satisfaction level to their jobs. The longer an employee works in an organization the more valuable it will be and they will be loyal and satisfied with their jobs.

From the past researches, the key organizational objective is Job satisfaction and is essential for higher competitive level and organizational success (Garcia Bernal et al., 2005). Defining the "Satisfaction" is, "final state of a psychological process" (Garcia-Bernal et al., 2005). There is no worldwide definition of "job satisfaction", but it is a multi-dimensional concept which includes asset of favorable or unfavorable feelings, which the employees perceive from their jobs. (Davis and Newstrom, 1999).Job satisfaction is a new term, which tells that how much any person is satisfied and contented with their job. In past times jobs are not available like todays. People's jobs are already fixed what their ancestors were doing or what profession they belong to.

Job satisfaction can also be observed general attitude of the employee towards his or her job. This shows that how much an employee is satisfied by his or her job. Locke (1976) explained job satisfaction as positive influence of employees towards their job. Job satisfaction has become the most significant and repeatedly studied attitude in the field of management 
sciences. According to Mitchel \&Larsel Hoppock (1987) job satisfaction is the combined reactions based on psychological, physiological and environmental orders or disorders which makes an employee to say that he or she is satisfied or not. Robbins (2005) on the other hand explained that job satisfaction is all about the feelings of a person about his or job. Job satisfaction is a particular view of the work with which employees views their job and this view is affected by favorable and unfavorable feelings and attachments of one's work (Newstrom, 2007).

In the eyes of Wanous and Lawler (1972) job satisfaction is the effective direction towards desired results. Some researchers defined job satisfaction as the feelings of employees about their job (Arches, 1991). Cranny et al (1992) indicated that it is all about reactions of the employees good or bad which are the results of comparison of actual and desired results.

Loyalty as defined in Encyclopedia Britannica (1998) is how much a person have attachment to a particular object, further that object can be anything; a person, a group of persons, an ideal, a particular job, or any cause which makes him or her to show devotion. Loyalty itself expresses by the persons struggle for doing good things for that particular object, such actions that shows his or her interest in that object.

Employees' loyalty is often viewed as the attitude towards a particular organization. Meyer \& Allen (1991) however argued that loyalty is not so much the attitude that is important in organization but the action is of great impact. Solomon (1992) establishes that employee's loyalty is the eagerness to stay touched with the organization.

Employee loyalty is an organizational citizenship behavior that reflects the all egiance to the organization to the promotion of its interests and image to the outsiders. (Bentten Court, Gwinner and Meuter, 2001). We can say that an employee is loyal to his or her organization when he shows commitment and believes that it is the best option for him or her to work for the organization.

Job Satisfaction is a major factor to enhance and maintain theoverall yield of organization and the job loyalty by efficient service and better performance. Many researchershave created the links between job satisfaction and other factors like stress and burnout, motivation, turnover intention workplace environment, organizational commitment, empowerment, performance, turnover intention and personal characteristics. (Chen, 2006; Fair brother and Warn, 2003; Furnham et al., 2002; Gaertner, 1999; Ghiselli et al., 2001; Jernigan et al., 2002; Karatepe et al., 2006; Lam et al., 2001; Linz, 2003; Silva, 2006; Spence Laschinger et al., 2002; Tepeci and Bartlett, 2002; Tsigilis et al., 2004).

Porter and Steers (1973) argued that job satisfaction reflects the aggregate level of net worker prospects and they remain loyal to their jobs. Employees want some other benefits along with their jobs like promotion, pay, autonomy etc. These benefits and range of their preferences may be different for every job but if these benefits remains unmet then their satisfaction level will decline and lead to the withdrawal behavior.

Objectives of the study is to develop standardize and measures to evaluate job satisfaction and job loyalty. And what factors affect the satisfaction level of job. To find out the factors 
affecting satisfaction of job and which directly affect the loyalty level. Also identify new areas for further research. Some researches on job satisfaction have been addressed different variables into two categories: personal traits of employees and the job characteristics (Reiner and Zhao, 1999). In this study we will check the characteristics which affect the satisfaction level of job.

\section{Literature review}

In this study we mainly focus on satisfaction level of job and Job loyalty, the factors affecting job satisfaction. Also some other variables have been discussed here which affect satisfaction level on job.

\subsection{Job satisfaction and loyalty}

The Loyalty of the employees mean that he is willing to work in that organization where he is already work, he try their best for the success of the organization and he think to do work in that organization it is the best option for him. He decided not to leave and nor any plan to go in some other organization (The Loyalty Research Center, 1990). It is just like a behavior of citizenship who tries to increase the value of firm, its image as well as develop interest in outsiders mind (Bentten Court, Gwinner and Meuter, 2001).

According to Garcia -Bernal et al (2005), "The last state of psychological Process is called satisfaction". We should be defined job satisfaction in that context which is may be accepted as: The feelings of the employees and attitude in relation with job components such as the environment where he work, work place conditions, rewards such as salary and bonuses and job itself (Glisson and Durick, 1988; Kim et al., 2005).

In last, few years in the major organization, the employee's satisfaction and job satisfaction apparent to be a prerequisite for spirited levels of quality and organizational success has become a major objective (Garcia-Bernal et al. 2005). In the most of researches, it is define that if the behavior of the organization and environment of the organization is fit and the environment of the person dominates it (Mottaz, 1985; Kristof, 1996), it means the employees do their work in given time, values and characteristics of a person is high, than the degree of job satisfaction is positive.

According to the Walker (2005), relationship between job satisfaction and job loyalty would be positive if the organization provides different opportunities such as learn, grow and clear established career path. There is strong correlation between employee satisfaction and employee loyalty based on these variables, recognition and rewards, working conditions, relationship with supervisor teamwork (Fosam et al 1998). According to the McCusker\&Wolfman (1998); McGuiness, (1998); Selnow\&Gibert, (1997); Vardi et al, (1989) there is relationship between job satisfaction and job loyalty on the basis of these values honesty, trust, respect for others etc.. So on the basis of previous research there is positive relation between job satisfaction and job loyalty.

H1. Job satisfaction has a positive impact on the job loyalty. 


\subsection{Participation in decision making}

According to Knoop(1995), giving the power to make decision with them to meet ultimate objectives is Participation in Decision making (PDM). Participation in decision making means to provide an opportunity and give importance to their employee thinking whether they are unequal hierarchy. According to previous research suggest that high level of job satisfaction can be gained from participation in decision making. (Cotton et al., 1988, p. 17). It is very important to note that employee like to participate in decision making and this participation lead to job satisfaction. According to (Richie and Miles, 1970) participation in decision making fulfill the need of employees ego and employee behavior will be more cooperative towards organizational objectives and goals .According to (Black and Gregersen, 1997; job satisfaction has been increased by PDM. we can say that when employee involved as a part of important information and planning processes, his level of satisfaction will be high and higher motivation will lead to higher job satisfaction.

The previous research shows that job satisfaction, increase due to participation in decision making (Pearson and Duffy, 1999). According to (Wager, 1994), Coch and French (1949) there is a relationship between participation in decision making and how they influence on job satisfaction. Luthans, (2005), Moorhead and Grifcin (2004), give a statement in his research shows that when the employee participate in decision making their level of absenteeism decreased, improved performance, organizational commitment greatly improved and job turnover decreases, whether job satisfaction increased. PDM have greater impact on job satisfaction because employee know his importance and feel power when they have authority to contribute its mental skills in any decision for the betterment of organization.PDM directly or indirectly effect the job satisfaction. PDM will also lead to influence to job characteristics, like effort, reward and performance, and job characteristics influence the job satisfaction.

\section{H2: There is a significant relationship of PDM and job satisfaction.}

\subsection{Empowerment}

Now days due to the high national and international competition the employers are showing positive behavior towards employee empowerment. different authors has described the concept of empowerment from different sides such as Hales and klidas (1998) has explained the concepts from the relationship and belongings aspects they said that the empowerment means to give knowledge, facts and authority to the colleagues. Empowerment includes giving employees freedom of actions to make decision how they go about their daily activities (Carless, 2004; Hass, 2010).all the business related and research related persons believe that the persons who are employees are the competitive advantage for the organizations (Etzioni; 1961, Siegall and Gardner; 2000). the concept of giving authority and freedom to the people who are employee can be searched easily from different places, as per companion approach (Lewin, 1951) join two categories of work in a planed process. The belief of improving the quality of job (Herzburg, Mausner et al., 1959; Harzberg, 1968) was 
focusing on enhancing the authority and participation in decision making in one's job. it is fact that before 1990 the idea of giving authority to the employee could only be approached by means of articles in which certain information or we can say the knowledge is given for instance partake management, how to control the standard of product, personal development and strategic planning (Sullivan,1994).

If we took a view of articles in which the concept of employee empowerment is used as a key term we can see that this concept hasn't specific direction or limitation it can be used to explain individual as well as the organizational one (Honold, 1997). if we want to get desired results such as effectiveness of organization and management according to the leadership aspect we can achieve these results by empowering our subordinates this action is also called employee empowerment (Bennis, 1989 et al). another direction of employee empowerment in the detailed examination of inside authority and command of an organization showed that by giving information about facts and authority to the subordinate enhance the organizational effectiveness (Kanter, 1979; Tannen baum, 1968).

It is fact that lot of definitions on the concept of employee empowerment is available but the mutual consensus on the all aspects of the concept is not available (Lee and Koh, 2001; Peccei and Rosenthal, 2001). a research shows the relationship among different constructs for instance it is believe that as the authority of the employee increased his internal motivation is also increased and by increasing level of job satisfaction the job stress can be decreased (Menon,1995). a research shows that the employee empowerment and job satisfaction has positive relationship (Bordin, Bartram, Gian, 2007).

\section{H3: There is a significant relationship between empowerment and job satisfaction.}

\subsection{Reward and Recognition}

Many types of programs exist for the reward and recognition of the employees. According to Bowen (2002) a reward is something given or received against for a service. Benefits received by the workers doing their jobs are included in reward (Kalleberg 1977, Mottaz1988). In simple words, a tangible gift which is given to one who has contributed something in organization. It can be of any form, a candy or monetary base. Reward can be given formally or informally or for completion of specific task. The acknowledgment of one's contribution to the organization in the eyes of public is called recognition (Bowen, 2002). One of the vital factors, which effect the job satisfaction, is reward and recognition. Maurer (2001) emphasized that we should consider the link between organizational successes as the consequence of employee job satisfaction. Reward and recognition is proved key factors, which influence the employee job satisfaction (Jun et al., 2006). No reward system and lack of recognition for completing the tasks, is the result of poor system, which is prevailing in typical organizations, such system that hinders in the way of supervisors to encourage their workers for doing a good job (Pascoe et al., 2002). Simply, poor reward and recognition system reduces job satisfaction. Cronin and Becherer (1999) emphasized that there is significant relation between reward and recognition and Jobsatisfaction as study conducted 
on nurses. There exist two major categories of reward; extrinsic and intrinsic. In our study our focus revolves around extrinsic factors of reward system. Helms (2006) emphasized that extrinsic reward such as money and promotions are motivating factors for employees. Extrinsic reward as described by many researchers are all those tangible reward that organizations try to provide their workers for keeping them motivated and satisfied, like promotion, benefits, job security, pay, better working conditions (Kallberg,1977; Mottaz,1985; Price and Muller,1986; Tausky,1984). For getting good results, management should develop such reward and recognition system, which will enhance satisfaction of employees. The literature review regarding reward and recognition, we finally developed the hypothesis as:

\section{H3: There is significant and positive relationship between reward and recognition and job satisfaction.}

\subsection{Work Place Environment}

In the beginning, physical environment of working was generally termed as "working conditions." Herzberg (1966) stated these working conditions as ventilation, lighting, tools, space, and other related environmental features, the amount of work and the facilities of the institution. Some other studies also analyzed the lighting effect, air quality and other parameters on physical health like fatigues, headache, pain, eye and nose, throat, skin irritation.

Some other researches acknowledged about human responses to the environment by different ambient conditions.(Brill 1984, Sundstrom \& SWldstrom, 1984; Wineman, 1982). The lighting, temperature and air quality, and noise includes in ambient conditions. Lunden (1972) calculated ten factors and Farrenkopf \& Roth (1980) studied about the eight factors of working environment with job satisfaction.

For the office environment lighting is very essential component, Brill (1984) analyzed that appropriate quantity of light and the lighting's quality are not independent factors. Brill (1984) also indicated that environmental conditions of air and temperature affect a person's perception of comfort. SundstrometaI. (1994) measured that disorder by noise from combined sources correlate inversely with composite measures of both environmental and job satisfaction.

Donald and Siu (2001) created the link between workplace environment, mental and physical well-being of employee and job satisfaction. Many other researchers also found the significant and positive linkage between environmental satisfaction, indoor environment and the job satisfaction. (Veitch et al., 2007; Tack and Patitu, 1992; Oldham and Fried, 1987; Carlopio, 1992; Wells, 2000; De Croon et 1., 2005).

Brill et al. (2001) analyzed that all the factors of workplace environment together accounts for $24 \%$ on job satisfaction level. But this study does not include work experience factors. On the other sideEllickson and Logson (2002) studied 14 factors as prospective predictors and explaining about $52 \%$ of variance for job satisfaction. However, Lee and Brand (2005) did 


\section{Al Macrothink}

International Journal of Learning \& Development

ISSN 2164-4063

2014, Vol. 4, No. 2

not find any relationship between environmental factors and job satisfaction and argued that it is due to missing the mediating relationship.

Based on this information, there appear to be many diverse factors that affect job satisfaction from physical work environment. Several studies have been conducted but there is still need to enhance the job satisfaction from work environment.

\section{H5: Working environment has a significant and positive effect on job satisfaction.}

\subsection{Proposed model}

Figure1: proposed model

\section{Research Methodology}

The present research is descriptive in nature. We can explain descriptive research as to describe a phenomenon or a situation. In descriptive research we describe the existing phenomenon rather than making any judgments. The core objective of descriptive research is

\section{Participation in Decision \\ Making}

\section{Empowerment}

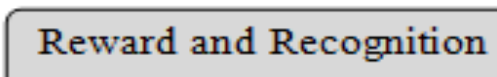

Workplace Environment

to verify the hypotheses that are developed on the basis literature review.

\subsection{Sample data}

For analyzing the job loyalty and impact of factors on job satisfaction level, a sample of 148 employees were taken from different departments; teachers, professor, administration, bankers, office employees both from public and private sectors. These samples have been taken from different institutions and organizations in Bahawalpur Pakistan.

This research was taken as a non-probability sampling technique that was a convenience sampling. Convenience sampling is the sampling technique in which samples were taken that 


\section{I Macrothink}

International Journal of Learning \& Development

ISSN 2164-4063

2014, Vol. 4, No. 2

were conveniently available (Zikmund, 1997) and to collect data speedily and economically (Lym et al., 2010)

For the better sample size, a $95 \%$ confidence level is used that tells that $5 \%$ of the result may vary from actual results. The 95\% confidence level is good level for the level of margin (Niles, 2006).

\subsection{Instrument and measures}

This survey study focuses on two major aspects: first one is to find the relationship of job satisfaction to job loyalty and the second one is to collect information about other factors which influence the job satisfaction level.

The survey contains two sections. Section $1^{\text {st }}$ includes the personal and demographic factors like gender, age, income and education. Section 2 includes the variables of the study. These variables includes participation in decision making, empowerment, reward and recognition and work place environment, job satisfaction and the job loyalty.

The scales of the study were taken from the published research papers and the literature. The scales for Job satisfaction and Job loyalty were taken fromWright, T.A and Cropanzano, R. (1998) and Chen Z.X et al., 1998 respectively. For the independent factors PDM, Reward and recognition, Empowerment and Workplace environment were taken from studies of Schutteetal., (1998), RoshanLevina Roberts (2005)Tsung-hsien et al., (2010) and Lee 2006 respectively.

\subsection{Procedures}

The questionnaire was distributed for getting response among various types of employees as mentioned above. Total 170 respondents were approached. Before getting respondent's view the purpose of study was briefly explained for the sake of understanding and clear response. Out of 170 questionnaires, 148 were selected for further analysis due to incomplete response remaining 22 was not included. In next step filled responses were added into SPSS sheet for further analysis.

\subsection{Reliability Analysis}

The results of analysis shows that the cronbach's alpha for all the scales were greater than 0.7 which is enough for the acceptable level, as the recommended value is 0.5 by Nunnally (1970) and 0.60 by Moss et al. (1990). It shows that all the 39 items were reliable. 


\section{Macrothink}

International Journal of Learning \& Development

ISSN 2164-4063

2014, Vol. 4, No. 2

Table 1:Reliability of measurement Instrument

\begin{tabular}{|l|l|l|}
\hline Scales & Items & Cronbach Alpha \\
\hline Workplace Environment & 8 & 0.836 \\
Reward \& Recognition & 6 & 0.829 \\
Empowerment & 7 & 0.733 \\
Participation in Decision making & 7 & 0.836 \\
Job satisfaction & 5 & 0.742 \\
Job loyalty & 6 & 0.776 \\
\hline
\end{tabular}

\section{Results and Analysis}

\subsection{Profile of Respondents}

Information about the personal and demographic factors; gender, age income, educational level and the variables of the research paper along with their frequencies; Reward and recognition, empowerment, workplace environment, PDM, job satisfaction and Job loyalty were included in the following table.

Table 2:Profile of the Respondents

\begin{tabular}{|c|c|c|c|}
\hline & Category & Frequency & Percentage \\
\hline \multicolumn{4}{|c|}{ Variable } \\
\hline \multirow[t]{2}{*}{ Gender } & Male & 118 & 79.7 \\
\hline & Female & 30 & 20.3 \\
\hline \multirow{7}{*}{ Age } & 20-30 Years & 98 & 66.2 \\
\hline & 30-40 Years & 26 & 17.6 \\
\hline & 40-50 Years & 17 & 11.5 \\
\hline & 50-60 Years & 6 & 4.1 \\
\hline & Above 60 Years & 1 & 0.7 \\
\hline & Below 15000 & 51 & 34.5 \\
\hline & $15000-25000$ & 37 & 25.0 \\
\hline
\end{tabular}




\begin{tabular}{|l|l|l|l|}
\hline Income & $25000-35000$ & 27 & 18.2 \\
$35000-45000$ & 11 & 7.4 \\
$45000-55000$ & 9 & 13 & 6.1 \\
& Above 55000 & 3 & 8.8 \\
\hline \multirow{5}{*}{ Education } & Matriculation & 7 & 2.0 \\
Inter & 35 & 4.7 \\
Bachelor & 88 & 23.6 \\
Master & 15 & 59.5 \\
MS / M. Phil & - & 10.1 \\
\hline
\end{tabular}

\subsection{Hypothesis testing}

\subsubsection{Work Place environment to Job satisfaction}

The regression results of the study reveals positive and significant relation between the workplace environment and Job satisfaction level, with $(\beta=0.257)$ and $(\rho<0.001)$. From these results, workplace environment contributes $25.7 \%$ to job satisfaction level. These results of the study validate $\mathrm{H} 5$.

\subsubsection{Reward\& Recognition to Job satisfaction}

Regression analysis job satisfaction tells us that job satisfaction and reward \& recognition has strong and significant relationship, with $(\beta=0.498)$ and $(\rho<0.001)$. These results tell that reward and recognition contribute $49.8 \%$ to job satisfaction. These analyses validate the hypothesis $\mathrm{H} 4$.

\subsubsection{Empowerment to Job satisfaction}

From the results of study it was found that job satisfaction and empowerment has significant and positive relation, with $(\beta=0.169)$ and $(\rho<0.05)$. This means that empowerment contributes $16.9 \%$ to the job satisfaction, so from these results we validate hypothesis $\mathrm{H} 3$.

\subsubsection{Participation in Decision making to Job satisfaction}

From the results it is found that there is insignificant relation between PDM and job satisfaction which has $(\beta=0.039)$ and $(\rho>0.05)$. Based on these results we concluded that the hypothesis $\mathrm{H} 2$ is rejected and has no significant value.

\subsubsection{Job satisfaction to Job loyalty}

While taking in account the significance of ultimate effect of job satisfaction to job loyalty, 


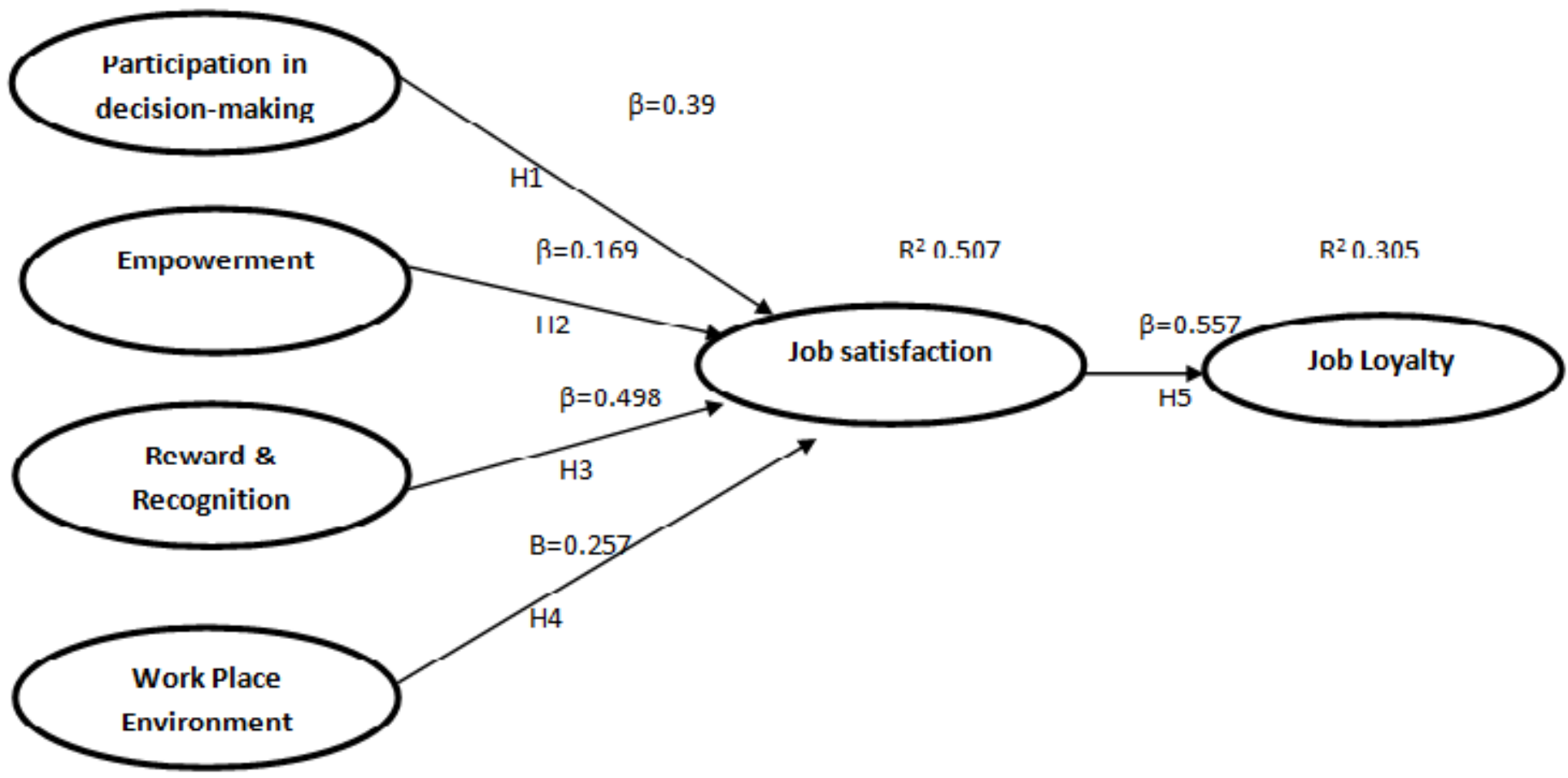

the results of current study shows that it has a strong relationship between them yet job loyalty has only one variable behind it with $(\beta=0.557)$ and $(\rho<0.001)$. It employs that job satisfaction contributes $55.7 \%$ to job loyalty. These results validate $\mathrm{H} 1$.

Table 3: Regression Results

\begin{tabular}{|l|l|l|l|l|l|l|}
\hline Hypothesis & Model Variables & Estimate & S.E. & C.R. & P & Results \\
\hline H1 & J. L. $\leftarrow$ J.S. & 0.557 & 0.061 & 8.097 & 0.000 & Supported \\
\hline H2 & J.S. $\leftarrow$ P.D.M. & 0.039 & 0.91 & 0.476 & 0.635 & Not Supported \\
\hline H3 & J.S. $\leftarrow$ Emp. & 0.169 & 0.90 & 2.113 & 0.26 & Supported \\
\hline H4 & J.S. $\leftarrow$ R. \& R. & 0.498 & 0.65 & 6.633 & 0.000 & Supported \\
\hline H5 & J.S. $\leftarrow$ W.P.E. & 0.257 & 0.090 & 3.292 & 0.00 & Supported \\
\hline
\end{tabular}

Figure2: Structure Model Result 


\section{Discussion and Recommendations:}

The main objective of this paper is to analyze the critical factors which affect the job satisfaction and its impact on job loyalty. Job Satisfaction has four main factors which are Participation in decision making, empowerment, reward and recognition, work place environment.

Reward and Recognition was the first major factor that affect job satisfaction with a value of its regression is0.498 and ( $\mathrm{p}<0.001)$. Organizations have to develop formal reward based systems to encourage the involvement in jobs. Recognition of excellence on related efforts by any employee, department should be rewarded as a means of supporting particular performance level. Reward system should be prepared in the organization based on individual performance.

In this research workplace environment was the second most important factor which affect the job satisfaction level. Workplace environment has a significant value with $(\beta=0.257$; $\rho<0.00$ ). Job satisfaction can be influenced by the quality of the physical environment in which they fulfill in their work. Whether work is physical or cognitive, it is performed in an environment that includes both physical and social aspects. Working conditions include satisfactory work space, appropriate lighting, noise, thermal environment, usability-related issues and office equipment. Ergonomic design of office workplaces increases the organization performance. Management should create a new concept for work environments to improve worker effectiveness

For creating the satisfaction level of Job, a high level of empowerment and reward based system must be given by the management. Empowerment is the third important factor which effect job satisfaction level with $(\beta=0.169 ; \rho<0.05)$. Involvement of empowered employees is due to the quality improvement processes. Without empowerment systems most employees' involvement fails whether organizations use suggestion system or regular meetings or not. When organizations apply leadership development they should include empowerment techniques as the key constituent of these programs.

The last factor participation in decision making was found from the analysis insignificant with $(\beta=0.039 ; \rho>0.05)$. Due to the factor, employees don't want to participate in any of the work and management decisions. Or the organizations don't want the employees to participate in any of decision makings. They want to be structured job with minimal changes in their work especially in smaller cities like Bahawalpur. So management has to encourage and motivate employees to participate in every decisions of the organization.

A satisfied worker can also be a loyal to his organization, from the study it was found that single factor of job satisfaction contribute $55.7 \%$ to job loyalty with $(\beta=0.557 ; \rho<0.001)$ which is a handsome relation between two. Some other factors also are there which help in job loyalty yet management have to try to enhance the satisfaction level so employees will be loyal to their jobs and organizations also. 


\section{Conclusion and limitation}

Number of studies has been worked out to identify the satisfaction level in job and the loyalty of job from the satisfaction level. These factors have been revealed from many past researches but information is still insufficient. For the reason, a conceptual model is developed to verify the influencing factors of Job satisfaction in developing country like Pakistan.

Job satisfaction (JS) is a widely accepted factor for success of any organization; the study focuses on the JS and its influencing factors and also the relation to loyalty to their jobs. Four factors of JS have been taken namely; participation in decision making, empowerment, reward and recognition, workplace environment. The results of study clearly show that there is positive and strong relation between JS to job loyalty. More than half of the job loyalty is due to the JS level. Most affecting factors to job satisfaction are reward and recognition, work place environment and empowerment, yet PDM is insignificant to Job satisfaction.In the modeling, statistically there is significant relationship between independent variables and JS.

This study has some of the limitations. As the analysis of this study shows that there is JS and job loyalty has positive and significant relationship yet they can't be generalized to whole population in Pakistan due to the sample size is confined not only to small geographical area but sample is also small. So if the sample size and the area of study are increased the results will be more significant and accurate. It cannot be said that JS is only backed by these four factors yet there are many other factors which was not taken in this study.

In spite of some above mentioned limitations, this study contributes some to literature, as it is conducted in the organizations of small city of a developing country Pakistan. This study gives contribution to both academic and business employees in understanding of Job satisfaction and loyalty. This study helps managers that how JS of an employee can enhance the efficiency and effectiveness of an organization. Some other factors can also be taken to enhance the JS which can be further studied like turnover, training, teamwork, job security, employee performance, etc.

\section{References:}

Arches, J. (1991). Social Structure, Burnout, and Job Satisfaction, Social Work, 36(3), 202-206.

Aryee, S.andChen, Z.X. (2006), "Leader-memberexchangeinaChinesecontext: antecedents, the Mediating role of psychological empowerment and outcomes", Journal of Business Research, Vol.59, pp.793-801.

Baruch, Y. (1998), “Empowerment model sin organizations”, Career Development International, Vol.3No.2, pp.82-7

Bennis, W.G. (1989), "Organizations of the future", in Natemeyer, W.E. and Gilberg, J.S., Classics of Organizational Behavior, W.E., Interstate, Danville, IL, pp. 300-12. 
Bettencourt Lance A., Kevin P Gwinner and Mathew L Meuter (2001), “A comparison of attitude, personality and knowledge predictors of service oriented organizational citizenship behaviors", Journal of applied psychology 86 (1), 29-41

Black, J.S. and Gregersen, H.B. (1997), "Participative decision making: an integration of multiple dimensions", Human Relations, Vol. 50 No. 7, pp. 859-79.

Block, P. (1987), “The Empowered Manager: Positive Political Skills at Work”, Jossey-Bass, San Francisco, CA.

Boshoff, C.and Allen. (2000), "The influence of selected antecedents on front lines taff's Perceptions of service recovery performance", International Journal of Service Industry Management, Vol.11, pp.63-90

Bowen RB. Recognizing and Rewarding Employees. New York: McGraw-Hill, 2000.

Brill, M. (1984).Using office design to increase productivity. Buffalo, NY: Work place design and productivity, Inc.

Brill, M., Weidemann, S. and BOSTI Associates (2001)Disproving Widespread Myths About Workplace Design, Kimball International, Jasper, IN

Carless,S.A.(2004), “Does psychological empowerment mediate the relationship between Psychological climate and jobsatisfaction?”, Journal of Business and Psychology,Vol.18, pp.405-25.

Carlopio, J. R. \& Gardner, D.(1992). Direct and interactive effects of the physical work environment on attitudes. Environment and Behavior, 24(5), 579-601.

Chen Z.X., Farh J.L., Tsui A.S., (1998). "Loyalty to supervisor, organizational commitment, and employee performance: the Chinese case", Academy of management best paper proceeding s '98, pp.J1-9.

Chen, C.F. (2006), "Short report: job satisfaction, organizational commitment, and flight attendants' turnover intentions: a note", Journal of Air Transport Management, Vol. 12,pp. 274-6

Conger,J.A.andKanungo,R.N.(1988), “The empowerment process: integrating theory and practice”, Academy of Management Review,Vol.13No.3,pp.471-82

Cotton, J.L., Vollrath, D.A., Froggat, K.L., Lengnick-Hall, M.L. and Jennings, K.R. (1988), "Employee participation: diverse forms and different outcomes", Academy of Management Review, Vol. 13 No. 1, pp. 8-22.

Cranny, C.J., Smith, P.C., and Stone, E.F. (1992). Job Satisfaction: How People feel about their Jobs and how it affects their Performance. Lexington Books, New York.

Cronin SN, Becherer D. Recognition of staff nurse job performance: staff and manager perceptions. J NursAdm 1999 Jan;29(1):26-31.

Davis, K.Y. and Newstrom, J.W. (1999),ComportamientoHumano en al Trabjo: 
Comportamiento Organizational, 10th ed., McGraw-Hill, Mexico City

De Croon, E.M., Sluiter, J.K., Kuijer, P.P.F.M. and Frings-Dresen, M.H.W. (2005) the effect of office concepts on worker health and performance: a systematic review of the literature. Ergonomics, 48(2), 119-134

Donald, I. and Siu, O. (2001) Moderating the stress impact of environmental conditions: the effect of organizational com-mitment in Hong Kong and China.Journal of Environmental Psychology, 21,353-368

Ellickson, M.C. and Logsdon, K. (2002) Determinants of job satisfaction of municipal government employees. Public Personnel Management, 31(3), 343-358

Encyclopedia Britannica (1998), the Definition of Loyalty.

Etzioni, A. (1961), a Comparative Analysis of Complex Organizations: On Power, Involvement, And Their Correlates, the Free Press, New York, NY

Fairbrother, K. and Warn, J. (2003), "Workplace dimensions, stress and job satisfaction", Journal of Managerial Psychology, Vol. 18 No. 10, pp. 8-21

Farrenkopf, T., \& Roth, V. (1980). The university faculty office as an environment.Environment and behavior, 12(4), 467-477.

Force's security police”, Review of Public Personnel Administration, Vol. 19 No. 3, pp. 5-18

Fosam, E.B., Grimsley, M.F.J., and Wisher, S.J. (1998).Exploring models for employee satisfaction; with particular reference to a police force. Total Quality Management, Vol. 9, No. 2 and 3, pp. 235-47

Furnham, A., Petrides, K.V., Jackson, C.J. and Cotter, T. (2002), "Do personality factors predict job satisfaction?'Personality and Individual Differences, Vol. 33, pp. 1325-42

Gaertner, S. (1999), "Structural determinants of job satisfaction and organizational commitment in turnover models", Human Resource Management Review, Vol. 9 No. 4, pp. 479-93.

Garcia-Bernal, J., Gargallo-Castel, A., Marzo-Navarro, M. and Rivera-Torres, P. (2005), “Job satisfaction: empirical evidence of gender differences", Women in Management Review, Vol. 20 No. 4, pp. 279-88.

Ghiselli, R.F., La Lopa, J. and Bai, B. (2001), "Job satisfaction, life satisfaction and turnover intend among food service managers", Cornell Hotel \& Restaurant Administration Quarterly, April, pp. 28-37.

Glisson, C. and Durick, M. (1988), "Predictors of job satisfaction and organizational commitment in human service organizations", Administrative Science Quarterly, Vol. 33 No. 1, pp. 61-81.

Haas, M.R. (2010), “The double-edged swords of autonomy and external knowledge: analyzing Team effectiveness in a multinational organization", The Academy of Management 
Journal, Vol.53, p.989 1008.

Hackman, J.R. and Oldham, G.R. (1980), Work Redesign, , Addison-Wesley, Reading, MA.

Hales,C.andKlidas,A.(1998),“Empowerment in five-star hotels :choice, voiceor rhetoric?”, International Journal of Contemporary Hospitality Management,Vol.10No.3,pp.88-95.

Helms, M. M. (2006)."Theory X and Theory,"Encyclopedia of Management $\begin{array}{llll}\text { Education.Retrieved November } & 1, & 2008 & \text { from }\end{array}$ http://www.enotes.com/management-encyclopedia/ theory-X-theory-y.

Herzberg, F. (1966).Work and the nature of man. C level and, Ohio: The world publishing company.

Herzberg, F. (1968), “One more time: how do you motivate employees?”, Harvard Business Review

Herzberg, F., Mausner, B. et al. (1959), The Motivation to Work, John Wiley \& Sons, New York, NY.

Jernigan, I.E., Beggs, J.M. and Kohut, G.F. (2002), "Dimensions of work satisfaction as predictors of commitment type", Journal of Managerial Psychology, Vol. 17 No. 7, pp. 564-79.

Jun, M., Cai, S. and Shin, H. (2006), "TQM practice in maquiladora: antecedents of employee satisfaction and loyalty", Journal of Operations Management, Vol. 24, pp. 791-812.

Kalleberg, A.L. (1977). Work Values and Job Reward: A Theory of Job Satisfaction. American Sociological Review, 42: 124-43.

Kanter, R. M. (1989), "Change masters", in Natemeyer, W.E. and Gilberg, J.S., Classics of Organzation Behavior, Interstate, Danville, IL, pp.358-70.

Kanter, R.M. (1977), Men and Women of the Corporation, Basic Books, New York, NY.

Kanter, R.M. (1979), "Power failure in management circuits," Harvard Business Review, Vol. 57 No.4, pp. 65-75.

Karatepe, O.M., Uludag ־, O., Menevis ,, I., Hadzimehmedagic, L. and Baddar, L. (2006), "The effects of selected individual characteristics on frontline employee performance and job satisfaction", Tourism Management, Vol. 27, pp. 547-60

Kim, W.G., Leong, J.K. and Lee, Y. (2005), "Effect of service orientation on job satisfaction, organizational commitment, and intention of leaving in a casual dining chain restaurant”,Hospitality Management, Vol. 24, pp. 171-93.

Knoop, R. (1995), "Influence of participative decision-making on job satisfaction and organizational commitment of school principals", Psychological Report, Vol. 76 No. 2, pp. $379-82$.

Lam, T., Zhang, H. and Baum, T. (2001), “An investigation of employees' job satisfaction: 
the case of hotels in Hong Kong", Tourism Management, Vol. 22 No. 2, pp. 157-65

Lee, (2006), Expectations of employees toward the workplace and environmental satisfaction,Facilities, Vol. 24 No. 9/10, pp.: 343-353.

Lee, S.Y. and Brand, J.L. (2005) Effects of control over work-space on perceptions of the work environment and work out-comes. Journal of Environmental Psychology, 25(3), 323-333.

Lee,M.andKoh,J.(2001),“Is empowerment really an concept?”, International Journal of Human Resource Management, Vol.12No.4,pp.684-95.

Lewin, K. (1951), Field Theory in Social Sciences, Harper \& Row, New York, NY.

Linda Honold, (1997),"A review of the literature on employee empowerment", Empowerment in Organizations, Vol. 5 Is: 4 pp. 202 - 212

Linz, S.J. (2003), "Job satisfaction among Russian workers", International Journal of Manpower, Vol. 24 No. 6, pp. 626-52.

Locke, E. (1976), "The Nature and Causes of Job Satisfaction, in Handbook of Industrial and Organizational Psychology Edited by M.D. Dunnette (Chicago: Rand McNally, 1976), pp. 901-969

Lunden, G. (March J April, 1972). Environment problems of office workers. Build International, 1,90-93.

Luthans, F. (2005).Organisational Behavior (10th ed). New Yolk, McGraw-Hill Irwin.

Maurer, R. (2001), "Building a foundation for change”, Journal for Quality \& Participation, Vol. 24 No. 3, pp. 38-9.

McClelland, D.C. (1975), Power: The Inner Experience, Irvinton Press, New York, NY

McCusker, D., \&Wolfman, I. (1998).Loyalty in the eyes of employers and employees.Work-force, 77 (11), 12-14.

McGuinness, B.M. (1998). The change in employee loyalty. Nursing Management, 29 (2), $45-46$

Menon, S.T. (1995), Employee Empowerment: Definition, Measurement and Construct Validation, McGill University, Canada.

Meyer, J.P., \& Allen, N.J. (1991). A three-component conceptualization of organizational commitment. Human Resource Management Review, 1, 61-89.

Mitchell \&Larson(1987),People in Organisations,3 ed,McGrawHill,New York

Mottan, C. (1985) The relative Importance of intrinsic and extrinsic reward as determinants of work satisfac- tion. The Sociolo\&al Quarterly 26 (3), 365-385. 
Mottaz, C.J. (1985). The Relative Importance of Intrinsic and Extrinsic Rewards as Determinants of Work Satisfaction, Sociology Quarterly, 26, 365-385.

Mottaz, C.J. (1985). The Relative Importance of Intrinsic and Extrinsic Rewards as Determinants of Work Satisfaction, Sociology Quarterly, 26, 365-385.

Mottaz, C.J. (1988). Determinants of Organizational Commitment. Human Relations, 41(6): 467-482.

NY. Kristof, J. (1996). Person-Organization Fit: an Integrative Review of its Conceptualizations, Measurement, and Implications, Personnel Psychology, 49, 1-49.

Oldham, G.R. and Fried, Y. (1987) Employee reactions to work-space characteristics.Journal of Applied Psychology, 72(1), 75-80.

Pascoe, C., Ali, I.M. and Warne, L. (2002), "Yet another role for job satisfaction and work motivation - enabler of knowledge creation and knowledge sharing", Informing Science InSITE - "Where Parallels Intersect", June, pp. 1239-48.

Peccei,R.andRosenthal,P.(2001), "Deliveringcustomer-orientedbehaviorthrough empowerment: an empirical test of HRM assumptions", Journal of Management Studies, Vol.38No.6,pp.831-58.

Porter, L.W. and Steers, R.M. (1973). Organizational Work and Personal Factors in Employee Turnover and Absenteeism, Psychological Bulletin, 80, 151-176

Price, J. L. and Mueller, C. W. (1Y86a) Absenteeism and Turrmwarnoq Hospital Ewploym. JAI Press, Greenwich. CT.

Reiner, M.D. and Zhao, J. (1999), "The determinants of job satisfaction among United States Air

Robbins, S. P. (2005), Organizational Behavior, 11th ed., Pearson Prentice Hall, New Jersey.

Selnow, G.W., \& Gilbert, R.R. (1997).Charge managers with inspiring loyalty. Workforce, 76 (10), 85-87.

Siegall, M.andGardner, S. (2000),“Contextual factors of psychological empowerment”, Personnel Review, Vol.29No.6, pp.703-23

Silva, P. (2006), "Effects of disposition on hospitality employee job satisfaction and commitment", International Journal of Contemporary Hospitality Management, Vol. 18 No. 4, pp. 317-28

Solomon, C.M. (1992, Sept.). The loyalty factor, Personnel Journal, 52-62.

Spence Laschinger, H.K., Finegan, J. and Shamian, J. (2002), "The impact of workplace empowerment, organizational trust on staff nurses' work satisfaction and organizational commitment", Advances in Health Care Management, Vol. 3, pp. 59-85 
Spreitzer, G.M., Kızılos, M.A.andNason, S.W.(1997),“A dimensional analysis of the relationship Between psychological empowerment and effectiveness, satisfaction and strain”, Journal Of Management, Vol.23No.5, pp.679-704

Spreitzer,G.M.(1995),"Psychologicalempowermentintheworkplace:dimensions,measurement And validation”, AcademyofManagementJournal,Vol.38No.5,pp.1442-65.

Spreitzer,G.M.(1996), “Socialstructuralcharacteristicsofpsychologicalempowerment”, AcademyofManagementJournal,Vol.39No.2,pp.483-504.

Sundstrom, E., Town, 1.P., Rice, R.W., Osborn, D.P., \& Brill, M. (1994).Office noise, satisfaction, and performance. Environment and Behavior, 26(2), 195-222.

Sundstrom,E.,Town,1.P.,Brown,D.W.,Forman,A.,\&McGee,C.(1982). Physical enclosure, type of job, and privacy in the office. Environment and Behavior, 14(5), 543-559.

Tack, W. M.\&Patitu, L.C. (1992). Faculty job satisfaction: Women and minorities in Peril. Washington DC: The George Washington University.

Tannenbaum, A.S. (1968), Control in Organizations, McGraw-Hill, New York, NY

Tausky, C. (1984) i+'orknrrliSo\&q: -4 Iwodm-riot/ IO It $\sim$ drrstrial Sot-iolocy. F. E. Peacock, Itasca, IL.

Tepeci, M. and Bartlett, A.L.B. (2002), "The hospitality industry culture profile: a measure of individual values, organizational culture, and person-organization fit as predictors of job satisfaction and behavioral intentions",Hospitality Management, Vol. 21, pp. 151-70.

Thomas, K.W.andVelthouse,B.S.(1990), “Cognitiveelementsofempowerment”, Academy of Management Review,Vol.15No.4,pp.666-81

Tsigilis, N., Koustelios, A. and Togia, A. (2004), "Multivariate relationship and discriminant validity between job satisfaction and burnout", Journal of Managerial Psychology, Vol. 19 No. 7, pp. 666-75

Vardi, Y. Wiener, Y. \& Popper, M. (1989).The value content of organizational mission as a factor in the commitment of members. Psychological Reports, 65, 27-34.

Veitch, J.A., Charles, K.E., Farley, K.M.J. and Newsham, G.R. (2007) a model of satisfaction with open-plan office conditions: COPE field findings. Journal of Environmental Psychology, 27,177-189

Wagner, A.J. 1994. "Participation's effects on performance and satisfaction: A reconsideration of research evidence, "Academy of Management Review", vol.19, pp. 312-30.

Walker, R.M., and G.A. Boyne, (2005), Public Management Reform and Organizational Performance: An Empirical Assessment of the UK Labor Government's Public Service Improvement Strategy. Working Paper, Center for Local and Regional Government Research, Cardiff University

Wang, G. and Lee, P.D. (2009), "Psychological empowerment and job satisfaction: analysis of 


\section{Macrothink}

International Journal of Learning \& Development

ISSN 2164-4063

2014, Vol. 4, No. 2

Interactive effects, Group Organization Management, Vol.34No.3, pp.271-96.

Wanous, J.P. and Lawler, E. E. (1972). Measurement and Meaning of Job Satisfaction, Journal of Applied Psychology, 56(2), 95-104

Wells, M.M. (2000) Office clutter or meaningful personal dis-plays: the role of office personalization in employee and organizational well-being. Journal of Environmental Psychology, 20,239-255

Wineman, J. D. (1982). Office design and evaluation, Environment and Behavior, 14(3),271-298.

Wright, T.A and Cropanzano, R. (1998), "Emotional exhaustion as a predictor of job performance and voluntary turnover", Journal of Applied Psychology, Vol. 83, pp. 486-93. 